\title{
Application of ozonated water to maintain the quality of chicken meat: effect of exposure time, temperature, and ozone concentration
}

\author{
Eva Fathul Karamah ${ }^{1 *}$, and Nafila Wajdi $^{1}$ \\ ${ }^{1}$ Department of Chemical Engineering, Universitas Indonesia, Depok 16424, Indonesia
}

\begin{abstract}
As an environmentally friendly disinfectant, ozone now is being studied as an alternative to chlorine sanitizers in many segments of the food industry. The use of ozone as a superficial disinfectant of meat surfaces has been reported in the meat industry. Few studies on the use of ozone in chicken meat have been reported. Ozonated water treatments improve the quality and extend the shelf life of chicken meat. This research studied the effect of exposure time $(40,80$, and $120 \mathrm{~min})$, temperature contact $\left(3,26\right.$, and $\left.37^{\circ} \mathrm{C}\right)$, and ozone concentration $(0.21$ and $0.38 \mathrm{mg} / \mathrm{l})$ in the optimization of ozonated in effort maintain the quality of chicken meat. The observed quality parameters were total number of aerobic mesophyll bacteria, $\mathrm{pH}$, water content, and protein content. The results show that longer exposure time and lower temperature could lower the rate of decreasing quality in chicken meat. Ozonated water with $0.38 \mathrm{mg} / 1$ of ozone concentration is contacted with chicken fillet for 120 minutes at $3{ }^{\circ} \mathrm{C}$, it reduced aerobic mesophilic bacteria by $1 \mathrm{unit} \log \mathrm{cfu} / \mathrm{g}$. The ozone concentrations of 0.21 and 0.38 were able to disinfect total aerobic mesophilic bacteria of 0.42 and $0.89 \mathrm{log} \mathrm{cfu} / \mathrm{g}$ respectively. There was no significant effect on $\mathrm{pH}$ and chicken water content, but protein content decreased by $1 \%$.
\end{abstract}

\section{Introduction}

Indonesia is a country with high consumption of chicken meat. The average consumption of chicken meat in Indonesian society is 1.11 million tons/year with chicken meat production in Indonesia reaching 1.48 million tons per year (Outlook of Chicken Meat, 2016).

Despite the benefit of chicken meat as a affordable source of animal protein, chicken meat is also easily damaged. Rapid growth of microorganisms can change the quality of chicken meat.

Table 1. Terms of Microbiological Quality

\begin{tabular}{|c|l|l|l|}
\hline No. & Type & Unit & Counts \\
\hline 1. & $\begin{array}{l}\text { Total } \\
\text { Mesophilic } \\
\text { Aerobic }\end{array}$ & $\mathrm{cfu} / \mathrm{g}$ & Max. $10^{7}$ \\
\hline 2. & Coliform & $\mathrm{cfu} / \mathrm{g}$ & Max. $10^{2}$ \\
\hline 3. & $\begin{array}{l}\text { Staphylococcus } \\
\text { aureus }\end{array}$ & $\mathrm{cfu} / \mathrm{g}$ & Max. $10^{2}$ \\
\hline 4. & Salmonella $\mathrm{sp}$ & $\begin{array}{l}\mathrm{per} 25 \\
\mathrm{gr}\end{array}$ & Negative \\
\hline 5. & Escherichia coli & $\mathrm{cfu} / \mathrm{g}$ & Max. $10^{1}$ \\
\hline
\end{tabular}

(Sources: Indonesian National Standardization, 2009)

The methods currently used to maintain the quality of chicken meat include marinating, drying, and storage at cooler temperature $2-10{ }^{\circ} \mathrm{C}$ and freezing at $2-(-24){ }^{\circ} \mathrm{C}$. The bad side of marinating and drying is shifting the texture and taste of the chicken meat itself. While the cooling method requires intensive energy, thus higher cost. In addition, storage at low temperatures does not reduce the numbers of bacteria living inside chicken meat. It is only slowing down the growth rate of bacteria.

One of the food storage technologies capable of deactivating contaminant bacteria is by ozonation method. Ozone has been used to control odor, remove colors, decompose organic compounds, and disinfect pathogenic microorganisms in water and air. These powerful ozone-oxidation effects have been observed in various reactions even before the ozone molecule formula itself is discovered. In 1868, ozone was used to convert oil-oil mixtures into products that could be utilized as paints, varnishes, and clothing dyes. In 1870 patented an ozone-producing apparatus that could remove the smell of sewer (Rodríguez et al., 2008).

The effects of eradication of bacteria by ozone have been researched and documented. Leusink (2010) has proven that ozone is able to reduce the amount of Escherichia coli found. The effectiveness of ozone performance depends on the type and immunity of bacteria, viruses, and other pathogens against the dose of ozone, as well as the contact time of ozone with microorganisms (EPA, 1999a) in vegetables watercress and carrots.

However, the efficacy of ozone treatment on microbial reduction may be affected by many variables, such as bacterial contamination, form of ozone application, type of food surface, time of contact between ozone and foods,

\footnotetext{
*Corresponding author: eva@che.ui.ac.id
} 
$\mathrm{pH}$, temperature, chemical additives in the food, and the physicochemical composition of seafood (de Mendonça Silva, 2016).

Considering that chicken meat is one of the most common food in the world and in meat products industry, the use of ozone technology during chicken meat processing should be evauated. In this study, an ozonated water was contacted with chicken meat, with immersion technique, to evaluate the effect of using water method in maintaining the quality of chicken meat.

\section{Methodology/Experimental}

This study consists of two parts, which are the preparation of the ozonated water and the initial characterization.

\subsection{Chicken Meat Preparation}

Chicken meat that is used in this research is in the form of fillet or boneless. Chicken fillet is purchased one 12 hours before being treated with ozonated water. It is obtained from "Ranch Market" Pondok Indah, Jakarta. The chicken fillet was initially washed with distilled water before being used as sample in the freezer afterwards.

Sample is cut and weighted into a uniform size before being placed in each contactor. Each sample's weight is 100 grams. Sterile knife is used when cutting the fillet.

\subsection{Ozonated Water Preparation}

Ozonated water was prepared by ozonating tap water with a middle scale ozone generator (Aquasuper) and used immediately after the desired ozone concentration was achieved. The system was equipped with an erlenmeyer as a contact tank and gas inlet tube fitted with a stone bubbler-type diffuser. Ozone gas was produced from dry air by means of a corona discharge generator with a capacity of 523 grams ozone/h.

The tap water $\mathrm{pH}$ is 5.10 and has E.coli content of 1.8 $\mathrm{cfu} / \mathrm{g}$. Compared to bacteria contaminant standard in raw water, the maximum number of E.coli is $10 \mathrm{cfu} / \mathrm{g}$. Thus, it is considered a fine raw water for this ozone treatment

The N,N'-diethyl-p-phenylenediamine (DPD) reagent was used to determine the ozone concentration in water (Merck cat no. 1.00607.0001) and then concentrations were measured by spectrophotometer.

\subsection{Treatment of Samples}

About 100 grams portion of chicken fillet were immersed in $100 \mathrm{ml}$ of ozone solutions for $120 \mathrm{~min}$ at $26{ }^{\circ} \mathrm{C}$. The container used is a transparent Polyethylene Terephtalate (PET) with capacity of $200 \mathrm{ml}$, size $59 \mathrm{~mm}$ in diameter and $92 \mathrm{~mm}$ in height.

To determine the effect of temperature on the efficacy of ozone treatment, all the parameter qualities studied at three exposure time $(40,80,120 \mathrm{~min})$ at $26{ }^{\circ} \mathrm{C}$. temperature levels $\left(3,26\right.$ and $\left.37{ }^{\circ} \mathrm{C}\right)$ at $0.38 \mathrm{mg} / 1$ ozone concentration for $120 \mathrm{~min}$. Optimization was done according to ozone concentration, with comparison of 0.21 and $0.38 \mathrm{mg} / \mathrm{l}$.
After immersion finished, the ozonated water were removed from the container until dry and then the container was sealed and moved into chiller $3{ }^{\circ} \mathrm{C}$ for 168 hours after. The characteristics of sample were tested on the next $0,1,72,120$, and 168 hours. The parameter quality tested including total mesophilic aerobic bacteria, $\mathrm{pH}$, water content, and protein.

\subsection{Quality Analysis}

\subsubsection{Microbiological Analysis}

Total mesophilic aerobic bacteria is measured by the total plate count (TPC) method, resulting in log colony forming unit per gram of sample (log cfu/g). Shredded chicken fillet samples $(25 \mathrm{~g})$ were transferred into $225 \mathrm{~mL}$ of $0.1 \%$ sterile peptone water and homogenized for $2 \mathrm{~min}$ in a stomacher blender (Seward Model 4000, AGB Sci., Dublin, Ireland). One milliliter of the slurry was serially diluted in $0.1 \mathrm{~g} / 100 \mathrm{~g}$ peptone water and inoculated onto the enumeration media. Aerobic mesophilic bacteria counts were enumerated using Plate Count Agar (PCA, Oxoid, Basingstoke, UK) after incubation at $30{ }^{\circ} \mathrm{C}$ for 48 $\mathrm{h}$ and at $3{ }^{\circ} \mathrm{C}$ for 168 hours, respectively.

\subsection{2 $\mathrm{pH}$}

$\mathrm{pH}$ was measured using a commercial $\mathrm{pH}$ meter from Eutech Instruments 700 (Eutech Instruments, ThermoFisher Scientific, Singapore).

\subsubsection{Water Content}

Water content is determined by performing AOAC (Association of Official and Analytical Chemists) method, with equipments such as porcelaine plate, oven, and dessicator.

\subsubsection{Protein Content}

The percentage of protein content is measured with Kjeldahl method. 2 grams of the chicken fillet was transferred into $500 \mathrm{ml} \mathrm{Kjeldahl} \mathrm{flask.} \mathrm{Then} 2.5 \mathrm{~g}$ of $\mathrm{Na}_{2} \mathrm{SO}_{4}$ was added by shaking gently $25 \mathrm{ml}$ of concentrated tetraoxosulphate VI acid an oxidizing agent which digest the food, and a speck of selenium was added to serves as a catalyst, to the sample in the Kjeldahl flask. The flask was then set up in slanting position on the Bunsen burner inside the fume cupboard and then heated strongly till the mixture was bluish - green in colour. Digestion converts any nitrogen in the food to ammonia, and other organic matter to $\mathrm{CO}_{2}$ and $\mathrm{H}_{2} \mathrm{O}$. After digestion, the flask was then diluted with distilled water to about $200 \mathrm{ml}$ in the $250 \mathrm{ml}$ volumetric flask. $50 \mathrm{ml}$ of the digested sample was pipetted into the Kjeldahl distillation apparatus through the filling part of the apparatus into the inner chamber, $40 \% \mathrm{NaOH}$ was added and boiled. The ammonia distilled over, then condenses and reacted with a $10 \mathrm{ml}$ boric acid indicator to form ammonium borate. The distillation was stopped when the volume of 
ammonium borate solution reaches $50 \mathrm{ml}$. Then the distillate was titrated against $0.1 \mathrm{M} \mathrm{HCl}$.

\section{Result and Discussion}

\subsection{Effect of Exposure Time}

The first variation aims to see the effect of the exposure time in contacting the ozonated water on the quality of chicken meat. The longer the exposure time, the more ozone molecules are in contact with the sample. Duration of the exposure times varied between 40, 80, and 120 minutes. The parameters reviewed were changes in the aerobic mesophilic bacteria counts, $\mathrm{pH}$, moisture content, and protein content of chicken meat.

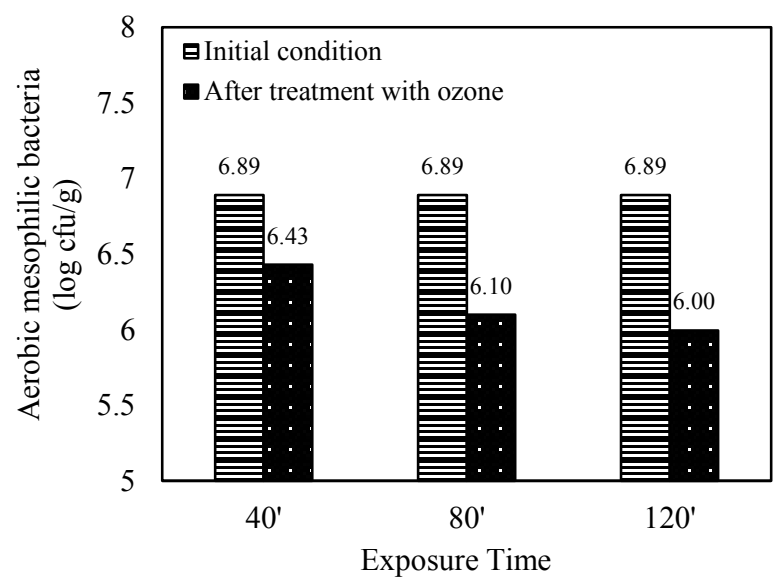

Fig. 1. Effect of ozone exposure time to aerobic mesophilic bacteria counts

The initial number of bacteria in the sample was log $6.89 \mathrm{cfu} / \mathrm{g}$. The contact duration of 40,80 , and $120 \mathrm{~min}$ respectively reduced the bacterial population by $\log 0.46$; 0.79 ; and $0.89 \mathrm{cfu} / \mathrm{g}$. From Figure 1, it can be seen that the ozonated water can reduce the total amount of aerobic mesophyll bacteria in chicken meat. Percentage decrease of each contact duration by $6.6 \% ; 11.6 \% ; 13 \%$ for each contact time of 40 ', 80' and 120 '. The trend of reduction of aerobic mesophyll bacteria shows that the longer exposure time of ozonated water with the sample, the higher the number counts of aerobic mesophyll bacteria has been disinfected.

The $\mathrm{pH}$ value obtained in the washing process of chicken meat sample using the water is shown in Figure 2 . The initial $\mathrm{pH}$ value of the sample is 6.22 . After contact with the aerated water, the three contact durations cause a decrease in $\mathrm{pH}$ value, but the $\mathrm{pH}$ value of the sample did not change significantly. The decrease in $\mathrm{pH}$ value is only about $0.01-0.02$. This suggests that ozone has no effect on the $\mathrm{pH}$ value of chicken meat.

Similarly, research conducted by Trindade et al. (2012), suggested that there was no change in the $\mathrm{pH}$ of chicken carcass washed with water with a concentration of $1.5 \mathrm{mg} / \mathrm{l}$ for 45 minutes. Manousaridis et al. (2005) considered that the effect of ozone on the $\mathrm{pH}$ value of chicken meat was not useful as a quality index, as it showed no change after treatment.

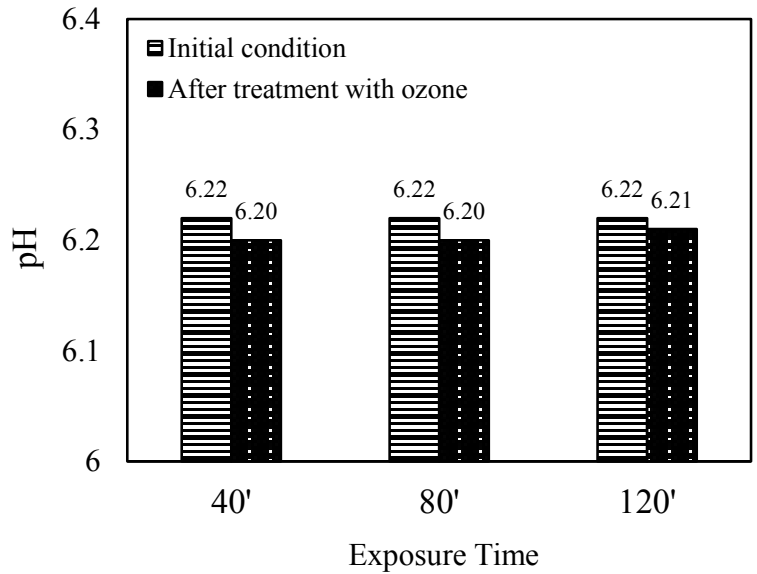

Fig. 2. Effect of ozone exposure time to $\mathrm{pH}$

Although there is no association between ozone and chicken $\mathrm{pH}$, changes in $\mathrm{pH}$ values can be analyzed from other interactions. This change in $\mathrm{pH}$ value can occur due to the effect of the reaction between ozone and organic compounds on the water. The effect of bacterial activity in chicken meat can also be a factor influencing $\mathrm{pH}$ change. Some bacteria have cell metabolism that produces acidic substances, such as Lactic Acid Bacteria (LAB), while some other bacterias such as Pseudomonas and Escherichia coli produces ammonia or indole that creates base atmosphere. Rouger (2017) states that if the population of LAB is more dominant, it will make the $\mathrm{pH}$ of the meat decrease.

In this case, Pseudomonas spp can be eliminated first when it comes into contact with ozone, leaving BAL in larger quantities. According to Brodowska et. al. (2017), the rate of deactivation of bacteria using ozone will vary for each species of microorganism. The susceptibility of the microorganism to ozone that he has identified is in the following order: Aspergillus niger $>$ Pseudomonas fluorescens $>$ Bacillus cereus $>$ Escherichia coli $>$ Bacillus subtilis $>$ Bacillus pumilus. Kim et al. (1999) identified that gram-positive bacteria, such as Lactobacillus and other LABs, are more resistant to ozone because they have more peptidoglycan on their cell walls. Gram-negative bacteria increase the permeability of ozone into the cytoplasm so that lysis can progress more quickly.

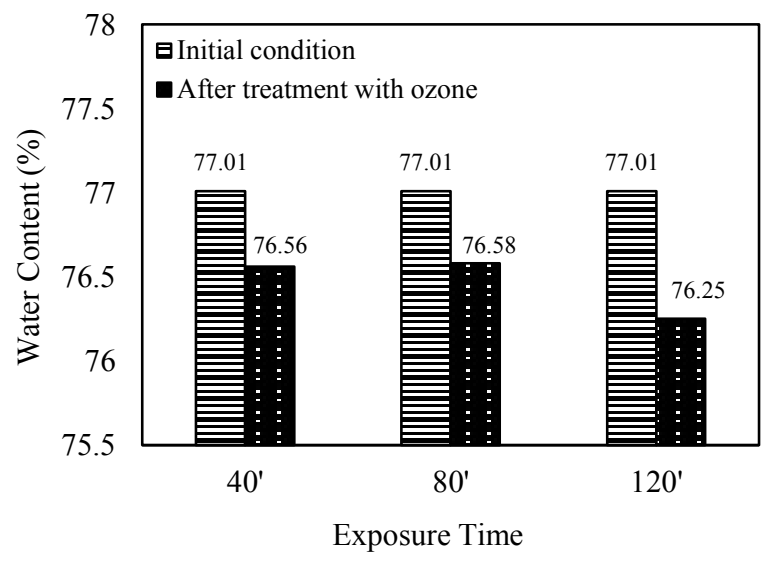

Fig. 3. Effect of ozone exposure time to water content 
The initial moisture content in the sample was $77.01 \%$. From Figure 3, it is shown that the moisture content of the sample decreases after contact with the water. The longer the exposure of the ozonated water with the sample, the water content will decrease even if it is not significant. The rate of decrease for contact time 40 minutes, 80 minutes, and 120 minutes in a row by $0.6 \%$; $0.6 \%$; and $1 \%$. This very small drop indicates that ozone does not have an insignificant effect on water content of chicken meat. However, there is still water released from chicken meat. This can happen because of the interaction of ozone with water-binding agents, such as bacteria or proteins. Certain types of bacteria, such as aerobic bacteria, produce a product of water from the result of cell respiration.

Certain types of bacteria, such as aerobic bacteria, produce a product of water from the metabolism of the cell. The more aerobic bacteria content, the greater the rate of increase in water content at which the bacteria multiply. In the previous explanation on effect to mesophilic aerobic bacteria, it has been observed that as the duration of contact increases, the number of mesophilic aerobic bacteria is reduced more and more. In this condition it can be indicated that the decrease in water content is caused by a decrease in the number of aerobic bacteria, which is the result of the ozone disinfection process against bacteria.

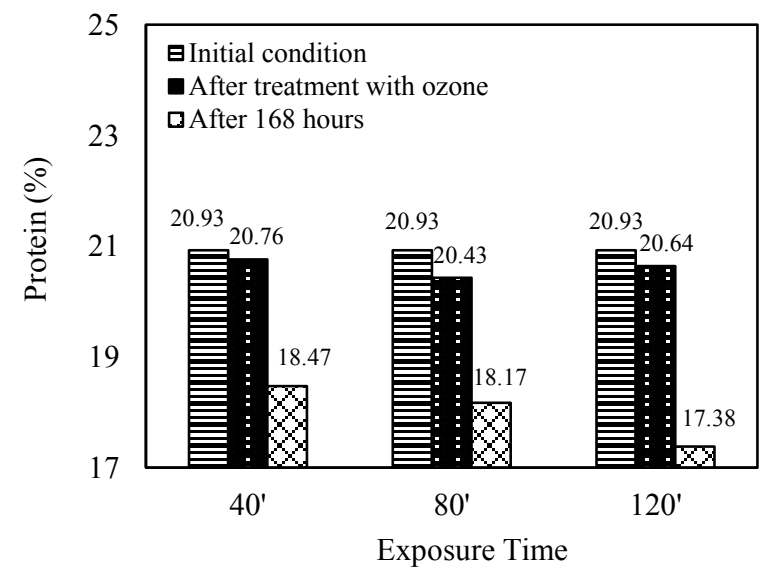

Fig. 4. Effect of ozone exposure time to protein content

Based on the results of protein content test, it appeared that there is a decrease in protein content after the chicken meat samples are contacted with water. Large decreases in protein content for contact time 40 minutes, 80 minutes, and 120 minutes respectively of $0.17 \% ; 0.5 \%$; and $0.3 \%$. The decrease in protein content after contact with ozone is very low, below $1 \%$, so it can be said that ozone has no effect on protein molecules. At the hour 168, the protein content is reassessed to determine whether or not the protein changes during the storage period. On the seventh day, the percentage decrease in protein content that occurs is quite large. This indicates that there is activity that causes protein in denatured chicken meat. The cause of this protein denaturation is due to the activity of proteolytic bacteria.

The factor which plays a role in changes in protein content in chicken meat is a microorganism, such as bacteria. According to Neiss (2015), proteins can be hydrolyzed into peptides and amino acids because they are assisted by bacteria that secrete proteases and peptidase enzymes. In chicken meat, the type of bacteria that process this protein are many from the Clostridium, Bacillus, Lactobacillus, Streptococcus, and Proteobacteria groups. The more the amount of bacteria, the greater the decrease in protein.

\subsection{Effect of Temperature}

This one studied the effect of room temperature on the optimization of ozonated water used to maintai the quality of chicken meat. The fixed variables in this study were chicken meat with 100 grams in weight, $100 \mathrm{ml}$ of ozonated water with $0.38 \mathrm{mg} / 1$ ozone concentration for $120 \mathrm{~min}$. The variations were conducted on the contact temperature, which was tested at three points is at refrigerator temperature $\left(3{ }^{\circ} \mathrm{C}\right)$, room temperature $\left(26^{\circ} \mathrm{C}\right)$, and incubator temperature $\left(37^{\circ} \mathrm{C}\right)$.

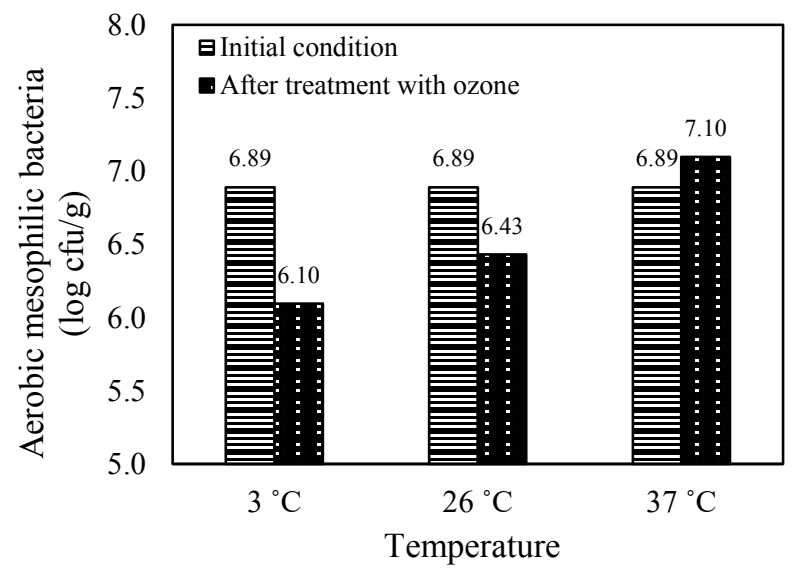

Fig. 5. Effect of temperature of ozonated water to aerobic mesophilic counts

From Figure 5, the treatments performed resulted in a decrease of aerobic mesophilic counts by $11.5 \% ; 6.7 \%$; $3 \%$ for each contact temperature $\left(3,26,37{ }^{\circ} \mathrm{C}\right)$. This shows that there is an influence between the temperature of the ozone contact on the quantity of aerobic mesophilic counts chicken meat. Wickramanayeke (1988), indicates that the inactivation rate constant of Naegleria gruberi spores is a function of ozone temperature and concentration. The trend of reduction of aerobic mesophyll bacteria shows that the lower the contact temperature will increase the percentage of disinfected aerobic mesophyll bacteria. At the incubator temperature, the number of aerobic mesophilic counts is increasing compared to the initial sample, because $37{ }^{\circ} \mathrm{C}$ is the optimum temperature of mesophilic bacteria to grow and reproduce themselves.

The $\mathrm{pH}$ obtained in the ozonation process of chicken meat sample using the water is shown in Figure 6. The initial $\mathrm{pH}$ value of the sample is 6.22 . In each temperature variation 3,26 , and $37^{\circ} \mathrm{C}$ the $\mathrm{pH}$ decreased to $6.16 ; 6.21$; and $6 ; 21$. This decrease in $\mathrm{pH}$ value is not caused by the interaction of ozone with chicken meat cells but can occur 
due to the metabolism of the chicken's own cell or due to changes in bacterial activity in the sample.

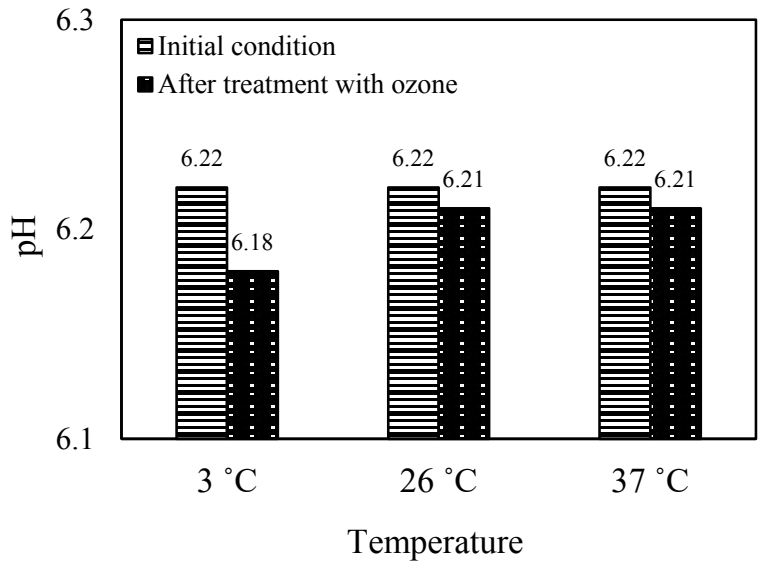

Fig. 6. Effect of temperature of ozonated water to $\mathrm{pH}$

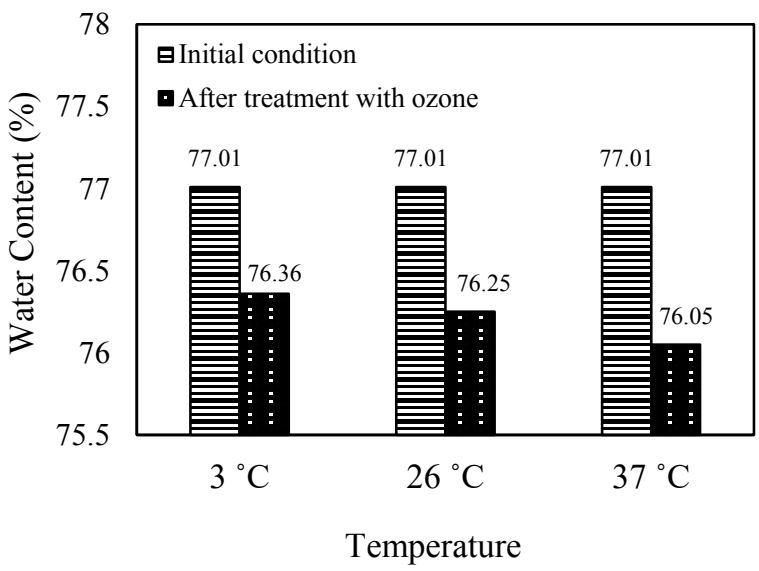

Fig. 7. Effect of temperature of ozonated water to water content

The rate of water content depletion for each temperature are $0.8 \% ; 1.2 \%$; and $1 \%$, respectively. This suggests that, directly the presence of ozone has an influence on water activity. Among the three temperatures, the most significant decrease was the incubator temperature $\left(37^{\circ} \mathrm{C}\right)$. As the temperature of contact increases, the amount of water content also decreases. This is due to the influence of temperature in the water activity. Water evaporates at a temperature of 0 - $100{ }^{\circ} \mathrm{C}$, and the amount of evaporation is directly proportional to the temperature. The relatively large drop in moisture content at the incubator temperature is caused by the evaporation of the water content of the sample.

The higher the contact temperature, the higher the protein depletion. Large decrease in protein content for temperature from $3,26,37{ }^{\circ} \mathrm{C}$ were $0.91 \% ; 1.1 \%$; and $2.05 \%$. As described in the previous section, ozone has little effect on proteins. In this case, a decrease in protein increases with increasing contact temperature can be caused by the effect of temperature on protein denaturation, not because of the ozone effect on the protein itself.

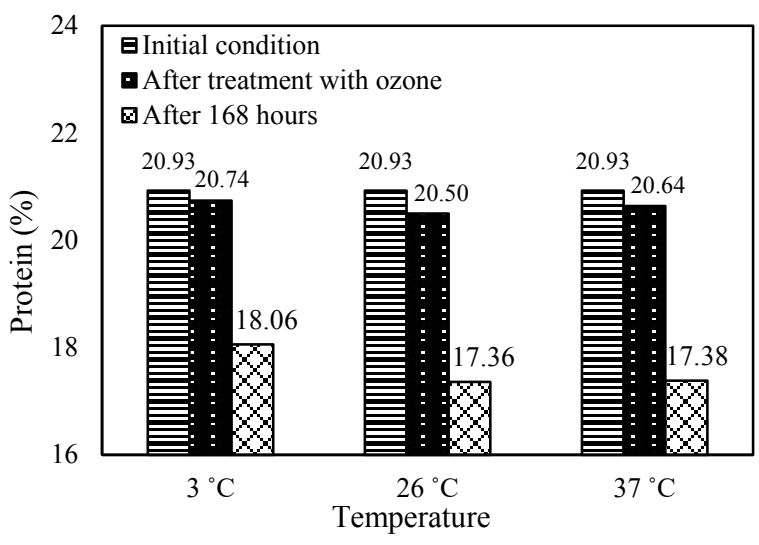

Fig. 8. Effect of temperature of ozonated water to protein content

\subsection{Effect of Ozone Concentration}

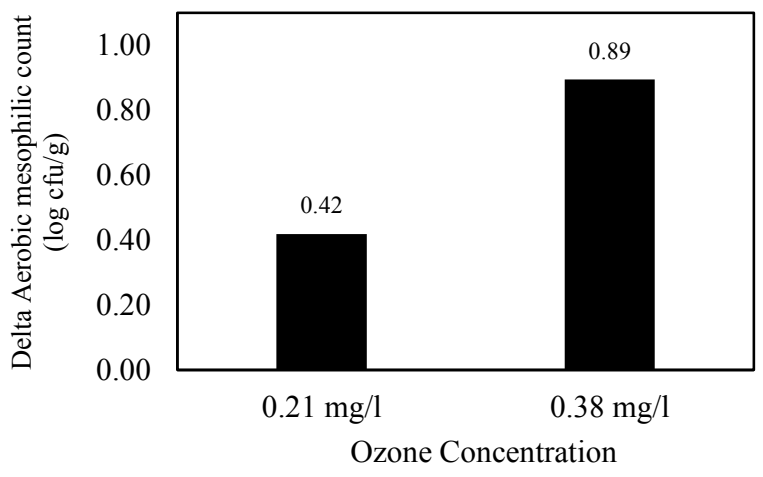

Fig. 9. Effect of ozone concentration on aerobic mesophilic counts

From Figure 9, the total number of aerobic mesophyll bacteria of the sample has decreased after contact with the water. After contact with the aerated water for 120 minutes, the total of aerobic mesophilic bacteria in the sample contacted with ozone dosage of $0.21 \mathrm{mg} / \mathrm{l}$ was counted down by $0.42 \mathrm{log} \mathrm{cfu} / \mathrm{g}$. For samples in contact with a dose of $0.38 \mathrm{mg} / \mathrm{l}$, total aerobic mesophilic bacteria decrease greater, $0.89 \log \mathrm{cfu} / \mathrm{g}$.

This indicates that the greater the ozone concentration in water, the more ozone molecules in the water, the greater the capacity of the aerobic water in reducing the total number of aerobic mesophyll bacteria. The reduction in the total number of aerobic mesophyll bacteria is caused by bacteria wall insertion by ozone so that ozone is unable to defend itself and then die or lysis.

Figure 10 shows that there was a decrease in the $\mathrm{pH}$ value of chicken meat after the contact of water treated with a sample of chicken meat for 120 minutes. Ozonated water with greater ozone concentration $(0.38 \mathrm{mg} / \mathrm{l})$ only decreases the $\mathrm{pH}$ value of chicken meat by 0.01 . While smaller ozone concentrations $(0.21 \mathrm{mg} / \mathrm{l})$ decreased the $\mathrm{pH}$ by 0.06 . This very small $\mathrm{pH}$ decrease indicates that the treated water treated with ozone concentration of 0.21 to $0.38 \mathrm{mg} / 1$ did not affect the $\mathrm{pH}$ of chicken meat. 


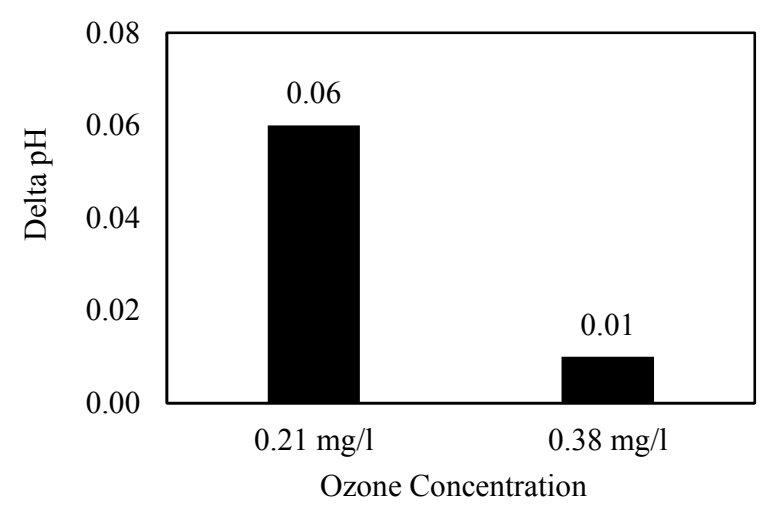

Fig. 10. Effect of ozone concentration on $\mathrm{pH}$

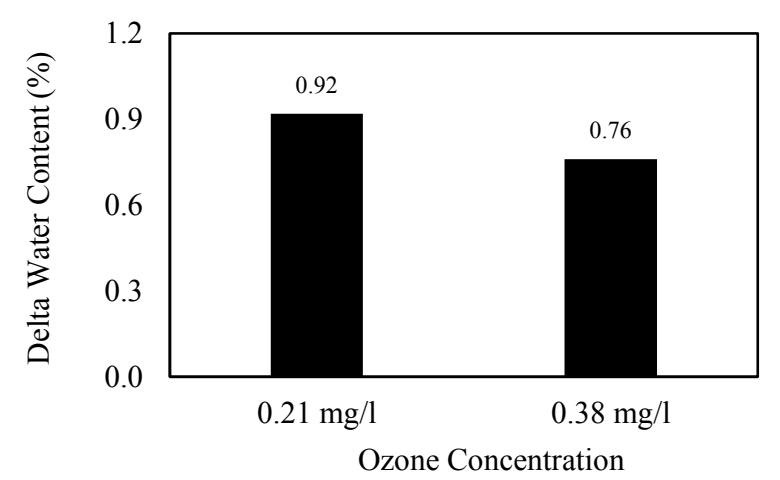

Fig. 11. Effect of ozone concentration on water content

From Figure 11, it can be seen that the moisture content of the sample decreases after contact with the water. After contact with the ozonated water for 120 minutes, the moisture content of the sample in contact with the dose of $0.21 \mathrm{mg} / 1$ decreased by $0.92 \%$. For samples in contact with a dose of $0.38 \mathrm{mg} / \mathrm{l}$, water content fell slightly, to $0.76 \%$. This very small drop (below $5 \%$ of baseline) indicates that ozone has no effect on chicken meat water content.

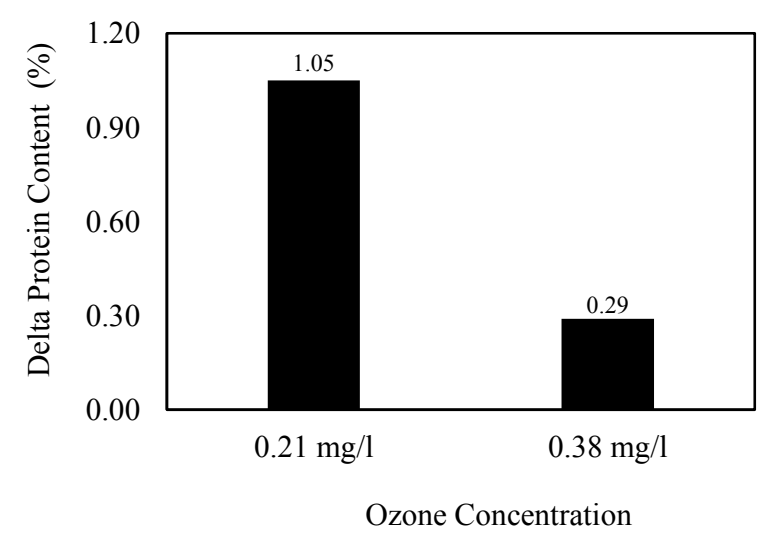

Fig. 12. Effect of ozone concentration on protein content

From Figure 12, it can be seen that the protein content of the sample decreased after contact with the water. Protein protein content was $20.93 \%$. The protein content of the samples dropped by 1.05 and $0.29 \%$, respectively, on treatments that were in contact with the doses of ozone 1 and 2. This indicates a decrease in the greater protein content at smaller ozone doses. This can be caused by the influence of bacterial activity when the disinfection process occurs. Referring to Figure 4.18, the amount of aerobil mesophyll bacteria disinfected at ozone concentration $0.38 \mathrm{mg} / \mathrm{l}$ is greater than the concentration of $0.21 \mathrm{mg} / \mathrm{l}$. This suggests that bacterial activity at ozone doses is $0.21 \mathrm{mg} / 1$ higher than other treatments.

\section{Conclusion}

Exposure time, temperature, and ozone concentration has an effect on the amount of mesophilic aerobic bacteria counts but it does not significantly affect the $\mathrm{pH}$, water content, or protein content of chicken meat. The longer the contact duration, the lower the temperature, and bigger concentration leads to greater the number of disinfected bacteria. Ozonated water with $0.38 \mathrm{mg} / \mathrm{l}$ of ozone concentration is contacted with chicken fillet for 120 minutes at $3^{\circ} \mathrm{C}$, resulting an aerobic mesophilic bacteria reduction by 1 unit $\log \mathrm{cfu} / \mathrm{g}$.

The author would like to thank all parties that have supported this study, especially Universitas Indonesia via Grant of International Publication Indexed for Thesis of UI's Students or known as PITTA 2018 (Grant no. 2433/UN2.R3.1/HKP.05.00/2018).

\section{References}

1. Alvarez-Astorga, M., Capita, R., Alonso-Calleja, C. \& Moreno, B., 2002. Microbiological quality of retail chicken by-products in Spain. Meat Science, Volume 62 , pp. $45-50$.

2. Brodowska, A. J., Nowak, A., Janyska, A. K. \& Piatkowski, M., 2017. Modelling the Ozone-Based Treatments for Inactivation of Microorganisms. International Journal of Environmental Research and Public Health, Volume 14, pp. 1196-1210.

3. de Mendonça Silva. 2016. Effect of aqueous ozone on microbial and physicochemical quality of Nile tilapia processing. Journal of Food Processing and Preservation, 41(6) pp. 1-7.

4. EPA, 1999. Alternative Disinfectans and Oxidants, Washington DC: EPA Guidance Manual.

5. Kim, J., Yousef, A. \& Davis, S., 1999. Application of Ozone for Enhancing the Microbiological Safety and Quality of Foods: A review.. Journal of Food Protection, Volume 62, pp. 1071-1087.

6. Leusink, J., 2010. How Does Ozone Kill Bacteria? [Online] Available at: http://www.ozonesolutions. com/journal/2010/how-does-ozone-kill-bacteria/ [Accessed on 11/02/2017].

7. Ghollasi-Mood, F., Mohsenzadeh, M., Housaindokht, M. R. \& Vardi, M., 2016. Microbial and chemical spoilage of chicken meat during storage at isothermal and fluctuation temperature under aerobic conditions. Iranian Journal Of Veterinary Science And Technology, 8(1), pp. 38-46.

8. Khalafalla, F., Abdel-Atty, N., Abdel-Wanis, S. A. \& Hanafy, A. S., 2015. Food Poisoning Microorganisms 
in Chicken Broiler Meat. Global Veterinaria, 14(2), pp. 211-218.

9. Rouger, A., Tresse, O. \& Zagorec, M., 2017. Bacterial Contaminants of Poultry Meat: Sources, Species, and Dynamics. MDPI Microorganisms, V(50), pp. 1-16.

10. Trindade, M.A., Kushida, M.M. 2012. Comparison of ozone and chlorine in low concentrations as sanitizing agents of chicken carcasses in the water immersion chiller. Journal of Food Protection, 75(6), pp. 11391143.

11. Wickramanayake, G.B. 1988. Ozone Concentration and Temperature Effects on Disinfection Kinetics. Ozone: Science \& Engineering, 10(2), pp. 123-135. 